\title{
Silanimonas lenta gen. nov., sp. nov., a slightly thermophilic and alkaliphilic gammaproteobacterium isolated from a hot spring
}

\author{
Eun Mi Lee, ${ }^{1,2}$ Che Ok Jeon, ${ }^{1}$ Inpyo Choi, ${ }^{1}$ Kyu-Seob Chang ${ }^{2}$ \\ and Chang-Jin Kim ${ }^{1}$ \\ ${ }^{1}$ Korea Research Institute of Bioscience and Biotechnology, 52 Oeundong, Yusong, \\ Daejeon 305-333, Republic of Korea \\ ${ }^{2}$ Department of Food Science and Technology, Chungnam National University, \\ 220 Gung-Dong, Yusong, Daejeon 305-764, Republic of Korea
}

Correspondence

Chang-Jin Kim

changjin@kribb.re.kr
Because moderately thermophilic bacteria are abundant in neutral hot springs, composts and even mesophilic environments and have great biotechnological potential for the production of thermoactive enzymes, a large number of these organisms have been isolated from various environments during the last few decades (Niehaus et al., 1999). Most of these bacteria belong to many different taxonomic groups, but the majority of the species within the phylum 'Proteobacteria' rarely grow at temperatures that exceed $45{ }^{\circ} \mathrm{C}$ (Alves et al., 2003). However, recently some members of the genera Thermomonas and Pseudoxanthomonas, belonging to the 'Proteobacteria' and showing slightly thermophilic properties, have been isolated from hot environments such as hot springs (Alves et al., 2003; Busse et al., 2002; Chen et al., 2002; Mergaert et al., 2003).

Published online ahead of print on 10 September 2004 as DOI 10.1099/ijs.0.63328-0.

The GenBank/EMBL/DDBJ accession number for the 16S rRNA gene sequence of strain $25-4^{\top}$ is AY557615.

The polar lipid content (Fig. A) and the fatty acid composition (Table A) of strain $25-4^{\top}$ are available as supplementary material in IJSEM Online.
They belong to the class 'Gammaproteobacteria' and have genomic DNA G $+\mathrm{C}$ contents in the range $64 \cdot 7-70 \cdot 1 \mathrm{~mol} \%$. Strain $25-4^{\mathrm{T}}$, a moderately thermophilic bacterium within the 'Gammaproteobacteria' and having a relatively low DNA $\mathrm{G}+\mathrm{C}$ content $(50 \cdot 7 \%)$, was isolated from a hot spring at Baekdoo Mountain in Korea. Here, we report the taxonomic characterization of this strain.

Strain $25-4^{\mathrm{T}}$ was collected from a hot spring of Baekdoo Mountain in Korea and isolated on nutrient agar (NA) after 2 days incubation at $45^{\circ} \mathrm{C}$. The isolate was routinely cultured aerobically on NA for 2 days at $47^{\circ} \mathrm{C}$. Growth was tested at different temperatures $\left(10-55^{\circ} \mathrm{C}\right)$ and at different $\mathrm{pH}$ values $(5 \cdot 0-11 \cdot 0)$. Media with different $\mathrm{pH}$ values were prepared using appropriate biological buffers: $\mathrm{Na}_{2} \mathrm{HPO}_{4} /$ $\mathrm{NaH}_{2} \mathrm{PO}_{4}$ buffer, $\mathrm{Na}_{2} \mathrm{CO}_{3} / \mathrm{NaHCO}_{3}$ buffer and $\mathrm{Na}_{2} \mathrm{HPO}_{4} /$ $\mathrm{NaOH}$ buffer were used for $\mathrm{pH}$ values below $8 \cdot 0$, $\mathrm{pH}$ values of 8.0-10.0 and pH 11.0, respectively (Bates \& Bower, 1956; Gomori, 1955). Strain $25-4^{\mathrm{T}}$ formed pale-yellow, translucent, flat, irregular, sticky colonies and grew at $\mathrm{pH}$ values from $6 \cdot 0$ to $10 \cdot 0$, with an optimum at $\mathrm{pH} 9 \cdot 0$. Growth was observed at temperatures between 25 and $53^{\circ} \mathrm{C}$, but not at $55^{\circ} \mathrm{C}$ (optimum temperature $47^{\circ} \mathrm{C}$ ). Strain $25-4^{\mathrm{T}}$ grew in nutrient broth containing $3 \%(\mathrm{w} / \mathrm{v}) \mathrm{NaCl}$, but not in that 
containing $5 \%(\mathrm{w} / \mathrm{v}) \mathrm{NaCl}$. Anaerobic growth was not observed after incubation in an anaerobic chamber for 5 days at $47^{\circ} \mathrm{C}$ on NA. Strain $25-4^{\mathrm{T}}$ was tested for its susceptibility to eight antimicrobial compounds (ampicillin, $10 \mu \mathrm{g}$; erythromycin, $30 \mu \mathrm{g}$; fusidic acid, $10 \mu \mathrm{g}$; gentamicin, $10 \mu \mathrm{g}$; kanamycin, $30 \mu \mathrm{g}$; lincomycin, $15 \mu \mathrm{g}$; neomycin, $30 \mu \mathrm{g}$; penicillin $\mathrm{G}, 10 \mathrm{IU}$; streptomycin, $10 \mu \mathrm{g}$ ) by using a method described previously (Alves et al., 2003): the strain was sensitive to all the antibiotics tested.

The cellular morphology of strain $25-4^{\mathrm{T}}$ was examined using light microscopy and transmission electron microscopy on cells grown on NA for 2 days at 37 and $47^{\circ} \mathrm{C}$. Each agarcoated wet mount used for motility observations was prepared by placing $10 \mu \mathrm{l}$ culture under a cover-glass on a glass slide that had been previously coated with a film consisting of $0.5 \%(\mathrm{w} / \mathrm{v})$ agarose (Cambrex). For visualization of the flagella, cells were mounted on Formvar-coated copper grids (Electron Microscopy Science) and negatively stained with $2 \%(\mathrm{w} / \mathrm{v})$ uranyl acetate for $15 \mathrm{~s}$, then subjected to transmission electron microscopy (JEM-1010; JEOL). Gram staining of strain $25-4^{\mathrm{T}}$ was determined using the bioMérieux Gram stain kit according to the manufacturer's instructions. Oxidase activity was tested using a Bactident Oxidase strip (Merck), whereas catalase activity was determined by bubble production in a $3 \%(\mathrm{v} / \mathrm{v})$ hydrogen peroxide solution. Hydrolysis of casein, L-tyrosine, starch, elastin, gelatin, aesculin and urea was determined as described by Lányi (1987). Acid production, by the isolate, from various carbohydrates was characterized using the API $50 \mathrm{CH}$ kit (bioMérieux) according to the manufacturer's instructions. Additional enzyme activities were tested using the API ZYM microtube system (bioMérieux), as recommended by the manufacturer. For quantitative analysis of whole-cell fatty acids, strain $25-4^{\mathrm{T}}$ was cultivated on NA for 2 days at 37 and $47^{\circ} \mathrm{C}$. Isoprenoid quinones and polar lipids from strain $25-4^{\mathrm{T}}$ were analysed according to the methods of Komagata \& Suzuki (1987). The genomic DNA $G+C$ composition of the isolate was determined by reversed-phase HPLC using the method of Kaneko et al. (1986).

The 16S rRNA gene of strain $25-4^{\mathrm{T}}$ was amplified and its sequence analysed as described previously (DeLong, 1992; Lane, 1991). The 16S rRNA gene sequence of the strain was aligned together with those of representative members of selected genera by using the CLUSTAL $\mathrm{W}$ program (Thompson et al., 1994). Sequence-similarity values were computed using Similarity Matrix, version 1.1 (http://rdp8. cme.msu.edu/html/; Cole et al., 2003). Gaps at the 5' and 3' ends of the alignment were omitted from further analyses. Phylogenetic trees were constructed using three different algorithms - neighbour-joining, maximum likelihood and maximum parsimony - available in PHYLIP software, version 3.6 (Felsenstein, 2002). Evolutionary distance matrices were calculated according to the algorithm of the Kimura twoparameter model for the neighbour-joining method. A bootstrap analysis (1000 replications) was performed to evaluate the stability of the phylogenetic tree with the neighbour-joining method in the PHYLIP package. The tree constructed by the neighbour-joining method showed that strain $25-4^{\mathrm{T}}$ formed a phyletic line that was distinct from those of the closely related genera Thermomonas, Luteimonas, Pseudoxanthomonas, Stenotrophomonas, Xylella and Xanthomonas (Fig. 1). The topologies of phylogenetic trees built using the maximum-likelihood and maximumparsimony algorithms were similar to that of the tree constructed by using neighbour-joining analysis (data not shown). Comparative 16S rRNA gene sequence analysis indicated that the strain is a member of the family 'Xanthomonadaceae' and has a unique taxonomic position within the class 'Gammaproteobacteria'. Strain $25-4^{\mathrm{T}}$ was most closely related to Thermomonas haemolytica DSM $13605^{\mathrm{T}}$, but with only $94 \cdot 4 \% 16 \mathrm{~S}$ rRNA gene sequence similarity, which is above the threshold level that is generally used to define a new genus (Ludwig et al., 1998).

Busse et al. (2002) reported that the flagellation type of $T$. haemolytica could only be visualized by staining, not by electron microscopy, and motility appeared only at higher temperatures $\left(37^{\circ} \mathrm{C}\right.$ and above). In contrast, a polar flagellum from strain $25-4^{\mathrm{T}}$ was observed under transmission electron microscopy, but not all cells had a flagellum. The proportion of cells with motility and flagellation was about $10-20 \%$. All other closely related taxa (except Rhodanobacter lindaniclasticus LMG $18385^{\mathrm{T}}$ ) in the phylogenetic tree shown in Fig. 1 also show polar flagellation (Nalin et al., 1999). The genomic DNA G + C content of the strain was $50.7 \mathrm{~mol} \%$, which is much lower than those of the closely related genera Thermomonas, Pseudoxanthomonas, Stenotrophomonas and Xanthomonas within the class 'Gammaproteobacteria', but is similar to that of the genus Xylella (Table 1). Despite the fact that strain $25-4^{\mathrm{T}}$ and $T$. haemolytica have similar physiological and chemotaxonomic properties, strain $25-4^{\mathrm{T}}$ was easily distinguishable from $T$. haemolytica by the large difference (about $18 \%$ ) in the genomic DNA G + C content.

The cellular fatty acids were analysed after growth of the strain at 37 and $47^{\circ} \mathrm{C}$. The predominant cellular fatty acids were the same at 37 and $47^{\circ} \mathrm{C}$, but the proportion of longchain fatty acids increased somewhat at $47^{\circ} \mathrm{C}$ (Table A, available as supplementary material in IJSEM Online). On $\mathrm{NA}$ at $47^{\circ} \mathrm{C}$, the isolate contained iso-branched fatty acids such as $\mathrm{C}_{15: 0}$ iso $(36.5 \%), \mathrm{C}_{16: 0}$ iso $(35.2 \%), \mathrm{C}_{17: 0}$ iso $(7 \cdot 6 \%), \mathrm{C}_{11: 0}$ iso $3-\mathrm{OH}(6 \cdot 6 \%), \mathrm{C}_{17: 0}$ iso cis $9(7 \cdot 6 \%)$ and $\mathrm{C}_{15: 0}$ iso $(2 \cdot 3 \%)$ as the major fatty acids, this being similar to the corresponding data for the closely related taxa (except Xylella fastidiosa) (Table 1). The predominant hydroxyl fatty acid of strain $25-4^{\mathrm{T}}$, T. haemolytica and Luteimonas mephitis was $\mathrm{C}_{11: 0}$ iso 3-OH. However, other related taxa, i.e. Pseudoxanthomonas broegbernensis, Stenotrophomonas maltophilia, Xylella fastidiosa and Xanthomonas campestris, contained different hydroxyl fatty acids such as $\mathrm{C}_{16: 0}$ 2-OH, $\mathrm{C}_{13: 0}$ iso $3-\mathrm{OH}$ and $\mathrm{C}_{10: 0} 2-\mathrm{OH}$ that were not even detected in strain $25-4^{\mathrm{T}}$ (Table A, IJSEM Online). The strain 


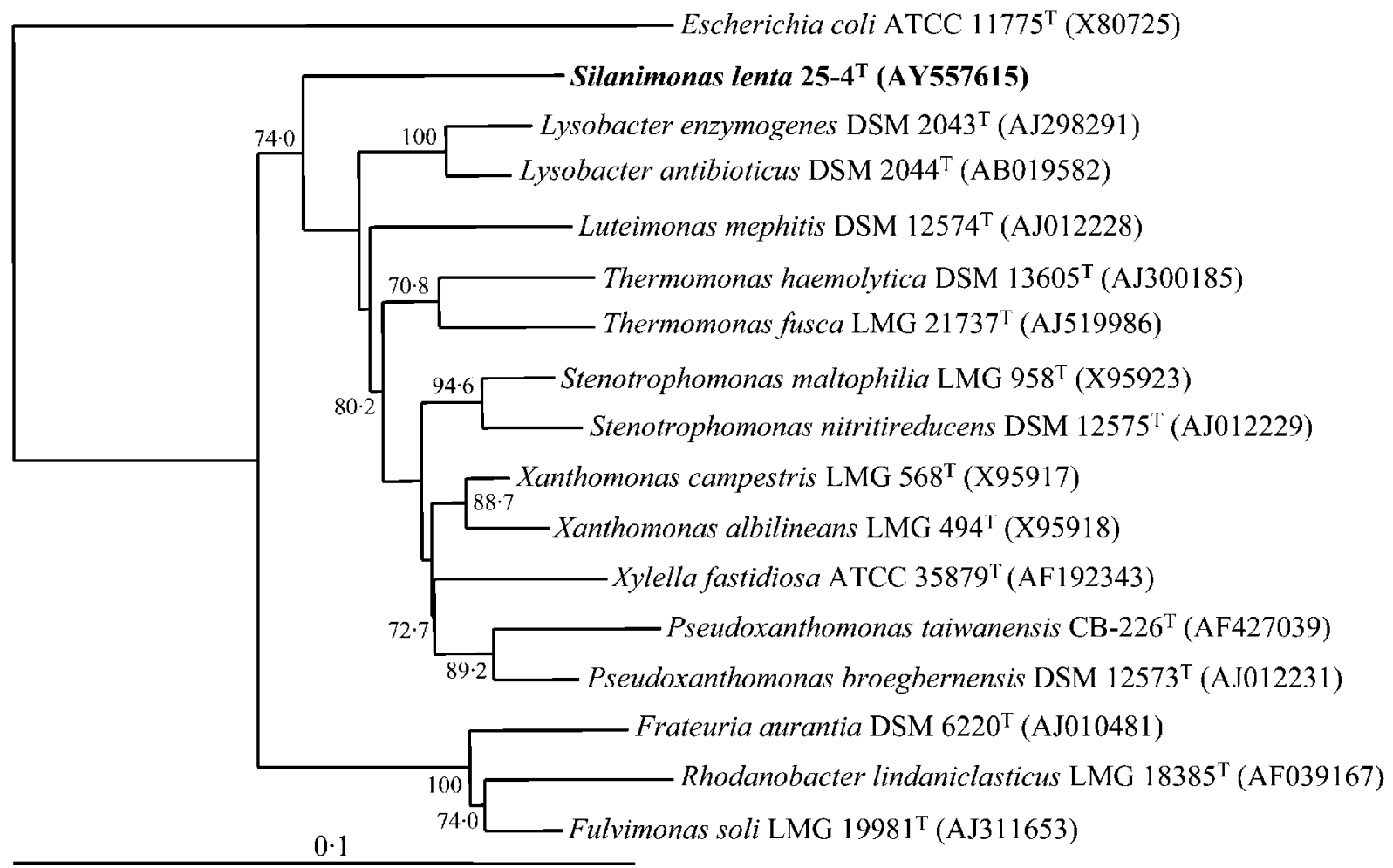

Fig. 1. Neighbour-joining tree showing the phylogenetic relationships between strain $25-4^{\top}$ and related taxa. Bootstrap probabilities based on a neighbour-joining analysis of 1000 resampled datasets are indicated at the nodes; only those values greater than $50 \%$ are indicated. The $16 \mathrm{~S}$ rRNA gene sequence of Escherichia coli ATCC $11775^{\top}$ was used as an outgroup. Bar, estimated number of base changes per nucleotide sequence position.

contained a large amount of an unknown phospholipid (PL1), a small amount of another unknown phospholipid (PL2) and one unidentified spot inferring the presence of glycolipids in addition to diphosphatidylglycerol, phosphatidylglycerol and phosphatidylethanolamine as the polar lipids (Fig. A, available as supplementary material in IJSEM Online). The presence of three unknown polar lipids was sufficient to distinguish the isolate from $T$. haemolytica. On the basis of its chemotaxonomic and phylogenetic properties, strain $25-4^{\mathrm{T}}$ represents a new genus, Silanimonas gen. nov., and novel species, Silanimonas lenta sp. nov., within the family 'Xanthomonadaceae' of the class 'Gammaproteobacteria'.

\section{Description of Silanimonas gen. nov.}

Silanimonas (Si.lan.i.mo'nas. L. m. silanus a fountain; L. fem. n. monas a unit, monad; N.L. fem. n. Silanimonas a monad isolated from a fountain).

Cells are strictly aerobic, Gram-negative, non-spore-forming rods. Oxidase- and catalase-positive. Nitrate is not reduced. Major isoprenoid quinone is Q-8. DNA G+C content is $50.7 \mathrm{~mol} \%$ (HPLC). Predominant cellular fatty acids are iso-branched fatty acids such as $\mathrm{C}_{15: 0}$ iso, $\mathrm{C}_{16: 0}$ iso, $\mathrm{C}_{17: 0}$ iso and $\mathrm{C}_{11: 0}$ iso $3-\mathrm{OH}$. Phylogenetically, the genus belongs to the family 'Xanthomonadaceae' within the class 'Gammaproteobacteria'.

The type species is Silanimonas lenta.

\section{Description of Silanimonas lenta sp. nov.}

Silanimonas lenta (len'ta. L. fem. adj. lenta sticky).

Colonies are pale yellow, translucent, irregular and sticky on NA. Cells are $0 \cdot 3-0 \cdot 5 \mu \mathrm{m}$ wide and $0 \cdot 8-1 \cdot 8 \mu \mathrm{m}$ long. Some, but not all, cells have a polar flagellum. The $\mathrm{pH}$ range for growth is $6 \cdot 0-10 \cdot 0$, with an optimum at $\mathrm{pH} 9 \cdot 0$. The temperature range for growth is $25-53{ }^{\circ} \mathrm{C}$, with an optimum at $47^{\circ} \mathrm{C}$. Starch, casein, L-tyrosine, elastin and gelatin are hydrolysed, but hydrolysis of aesculin, arbutin and urea is not observed. Alkaline phosphatase, esterase (C4), esterase lipase (C8), lipase (C14), leucine arylamidase, acid phosphatase, trypsin, $\alpha$-chymotrypsin and naphtholAS-BI-phosphohydrolase are produced, but valine arylamidase, cystine arylamidase, $\alpha$-galactosidase, $\beta$-galactosidase, $\beta$-glucuronidase, $\alpha$-glucosidase, $\beta$-glucosidase, $N$-acetyl- $\beta$ glucosaminidase, $\alpha$-mannosidase and $\alpha$-fucosidase are not produced. Acids are produced from D-glucose, fructose, ribose, maltose, cellobiose, aesculin and mannose, but not from glycerol, D-trehalose, D-xylose, L-arabinose, rhamnose, 
Table 1. Characteristics useful for differentiating strain $25-4^{\top}$ from representatives of related genera

Strains: 1, T. haemolytica; 2, Luteimonas mephitis; 3, P. broegbernensis; 4, Stenotrophomonas maltophilia; 5, Xylella fastidiosa; 6, Xanthomonas campestris; 7, Lysobacter enzymogenes. Data for strain $25-4^{\mathrm{T}}$ were generated in this study; all other data are taken from previous studies (Busse et al., 2002; Chen et al., 2002; Tóth et al., 2001; Finkmann et al., 2000; Vauterin et al., 1995, 1996; Palleroni \& Bradbury, 1993; Wells et al., 1987; Palleroni, 1984; Christensen \& Cook, 1978; Sullivan et al., 2003). Abbreviations: v+, most of the strains are not susceptible; $v^{-}$, most of the strains are susceptible; NA, not available; DPG, diphosphatidylglycerol; PE, phosphatidylethanolamine; PG, phosphatidylglycerol; PI, phosphatidylinositol; PME, phosphatidylethanolamine; PL, unknown phospholipid.

\begin{tabular}{|c|c|c|c|c|c|c|c|c|}
\hline Species & $25-4^{\mathrm{T}}$ & 1 & 2 & 3 & 4 & 5 & 6 & 7 \\
\hline Temp. optimum $\left({ }^{\circ} \mathrm{C}\right)$ & 47 & $37-50$ & 28 & 28 & 35 & $26-28$ & 28 & $25-35$ \\
\hline Polar flagellation & + & + & NA & + & + & + & + & - \\
\hline Catalase & + & + & NA & + & + & + & + & + \\
\hline Oxidase & + & + & NA & + & + & - & - & + \\
\hline Nitrate reduction & - & - & - & - & + & - & - & - \\
\hline \multicolumn{9}{|l|}{ Susceptibility to: } \\
\hline Ampicillin $(10 \mu \mathrm{g})$ & + & + & - & - & - & + & - & NA \\
\hline Penicillin G (10 IU) & + & + & - & - & - & - & - & - \\
\hline Erythromycin $(30 \mu \mathrm{g})$ & + & + & - & - & - & NA & - & NA \\
\hline Kanamycin $(30 \mu \mathrm{g})$ & + & + & $\mathrm{v}-$ & - & + & + & + & NA \\
\hline Neomycin $(30 \mu \mathrm{g})$ & + & + & $\mathrm{v}+$ & + & - & NA & - & NA \\
\hline Streptomycin $(10 \mu \mathrm{g})$ & + & + & - & - & - & - & + & - \\
\hline Major fatty acids & $\begin{array}{l}15: 0 \text { iso, } \\
16: 0 \text { iso }\end{array}$ & $\begin{array}{l}15: 0 \text { iso, } \\
16: 0 \text { iso, }\end{array}$ & $\begin{array}{c}15: 0 \text { iso, } \\
17: 1,17: 0 \text { iso }\end{array}$ & $\begin{array}{c}15: 0 \text { iso, } 15: 0 \\
\text { anteiso, } 16: 0\end{array}$ & $\begin{array}{c}15: 0 \text { iso, } \\
15: 0 \\
\text { anteiso }\end{array}$ & $\begin{array}{l}16: 0 \\
16: 1 \\
17: 0\end{array}$ & $\begin{array}{c}15: 0 \text { iso, } \\
16: 1 \\
17: 1 \text { iso }\end{array}$ & $\begin{array}{c}15: 0 \text { iso, } \\
17: 1 \text { iso } \omega 9 c\end{array}$ \\
\hline Major hydroxyl fatty acids & $\begin{array}{c}11: 0 \text { iso } \\
3-\mathrm{OH}\end{array}$ & $\begin{array}{c}11: 0 \text { iso } \\
3-\mathrm{OH}\end{array}$ & $\begin{array}{c}11: 0 \text { iso } \\
3-\mathrm{OH}\end{array}$ & $16: 02-\mathrm{OH}$ & $\begin{array}{c}13: 0 \text { iso } \\
3-\mathrm{OH}\end{array}$ & $\begin{array}{c}10: 0 \\
2-\mathrm{OH}\end{array}$ & $\begin{array}{c}13: 0 \text { iso } \\
3-\mathrm{OH}\end{array}$ & $\begin{array}{c}11: 0 \text { iso } \\
3-\mathrm{OH}\end{array}$ \\
\hline Major polar lipids & $\begin{array}{c}\text { DPG, PE, } \\
\text { PG, PL }\end{array}$ & $\begin{array}{c}\text { DPG, } \\
\text { PE, PG }\end{array}$ & NA & NA & $\begin{array}{c}\text { DPG, } \\
\text { PE, PG }\end{array}$ & NA & $\begin{array}{c}\text { DPG, PE, } \\
\text { PG, PME, PL }\end{array}$ & NA \\
\hline DNA G $+\mathrm{C}$ content $(\mathrm{mol} \%)$ & $50 \cdot 7$ & $68 \cdot 5$ & NA & $70 \cdot 1$ & $62-66$ & $51-53$ & $65-66$ & $69-70$ \\
\hline
\end{tabular}

lactose, adonitol, raffinose, mannitol, sucrose, arbutin, Dsalicin, sorbitol, erythritol or galactose. Major isoprenoid quinone is Q-8. Predominant polar lipids are phosphatidylglycerol, phosphatidylethanolamine, diphosphatidylglycerol and a large amount of an unknown phospholipid (PL1). The major cellular fatty acids on NA at $47^{\circ} \mathrm{C}$ are $\mathrm{C}_{15: 0}$ iso $(36 \cdot 5 \%), \mathrm{C}_{16: 0}$ iso $(35 \cdot 2 \%), \mathrm{C}_{17: 0}$ iso $(7 \cdot 6 \%)$, $\mathrm{C}_{11: 0}$ iso $3-\mathrm{OH}(6 \cdot 6 \%), \mathrm{C}_{17: 0}$ iso cis $9(7 \cdot 6 \%)$ and $\mathrm{C}_{15: 0}$ iso $(2 \cdot 3 \%)$. DNA G $+\mathrm{C}$ content is $50 \cdot 7 \mathrm{~mol} \%$ (HPLC).

The type strain of the species is $25-4^{\mathrm{T}}\left(=\mathrm{DSM} 16282^{\mathrm{T}}=\right.$ KCTC $12236^{\mathrm{T}}$ ).

\section{Acknowledgements}

This research was supported by the Microbial Genomics and Application Center of the 21st Century Frontier R\&D Program (MG020101-002-1-0-0) and the International Cooperation R\&D Program (grant M6-0203-00-0002) funded by the Ministry of Science and Technology of the Korean Government.

\section{References}

Alves, M. P., Rainey, F. A., Nobre, M. F. \& Cosata, M. S. (2003). Thermomonas hydrothermalis sp. nov., a new slightly thermophilic $\gamma$-proteobacterium isolated from a hot spring in central Portugal. Syst Appl Microbiol 26, 70-75.
Bates, R. G. \& Bower, V. E. (1956). Alkaline solutions for $\mathrm{pH}$ control. Anal Chem 28, 1322-1324.

Busse, H.-J., Kämpfer, P., Moore, E. R. B. \& 7 other authors (2002). Thermomonas haemolytica gen. nov., sp. nov., a $\gamma$-proteobacterium from kaolin slurry. Int J Syst Evol Microbiol 52, 473-483.

Chen, M. Y., Tsay, S. S., Chen, K. Y., Shi, Y. C., Lin, Y. T. \& Lin, G. H. (2002). Pseudoxanthomonas taiwanensis sp. nov., a novel thermophilic, $\mathrm{N}_{2} \mathrm{O}$-producing species isolated from hot springs. Int J Syst Evol Microbiol 52, 2155-2161.

Christensen, P. \& Cook, F. D. (1978). Lysobacter, a new genus of nonfruiting, gliding bacteria with a high base ratio. Int $J$ Syst Bacteriol 28, 367-393.

Cole, J. R., Chai, B., Marsh, T. L. \& 8 other authors (2003). The Ribosomal Database Project (RDP-II): previewing a new autoaligner that allows regular updates and the new prokaryotic taxonomy. Nucleic Acids Res 31, 442-443.

DeLong, E. F. (1992). Archaea in coastal marine environments. Proc Natl Acad Sci U S A 89, 5685-5689.

Felsenstein, J. (2002). PHYLIP (phylogeny inference package), version 3.6a. Department of Genetics, University of Washington, Seattle, USA.

Finkmann, W., Altendorf, K., Stackebrandt, E. \& Lipski, A. (2000). Characterization of $\mathrm{N}_{2} \mathrm{O}$-producing Xanthomonas-like isolates from biofilters as Stenotrophomonas nitritireducens sp. nov., Luteimonas mephitis gen. nov., sp. nov. and Pseudoxanthomonas broegbernensis gen. nov., sp. nov. Int J Syst Evol Microbiol 50, 273-282.

Gomori, G. (1955). Preparation of buffers for use in enzyme studies. Methods Enzymol 1, 138-146. 
Kaneko, T., Katoh, K., Fujimoto, M., Kumagi, M., Tamaoka, J. \& Katayama-Fujimura, Y. (1986). Determination of the nucleotide composition of a deoxyribonucleic acid by high-performance liquid chromatography of its enzymatic hydrolysates: a review. J Microbiol Methods 4, 229-240.

Komagata, K. \& Suzuki, K. (1987). Lipids and cell-wall analysis in bacterial systematics. Methods Microbiol 19, 161-203.

Lane, D. J. (1991). 16S/23S rRNA sequencing. In Nucleic Acid Techniques in Bacterial Systematics, pp. 115-175. Edited by E. Stackebrandt \& M. Goodfellow. Chichester: Wiley.

Lányi, B. (1987). Classical and rapid identification methods for medically important bacteria. Methods Microbiol 19, 1-67.

Ludwig, W., Strunk, O., Klugbauer, S., Klugbauer, N., Weizenegger, M., Neumaier, J., Bachleitner, M. \& Schleifer, K. H. (1998). Bacterial phylogeny based on comparative sequence analysis. Electrophoresis 19, 554-568.

Mergaert, J., Cnockaert, M. C. \& Swings, J. (2003). Thermomonas fusca sp. nov. and Thermomonas brevis sp. nov., two mesophilic species isolated from a denitrification reactor with $\operatorname{poly}(\varepsilon-$ caprolactone) plastic granules as fixed bed, and emended description of the genus Thermomonas. Int J Syst Evol Microbiol 53, 1961-1966.

Nalin, R., Simonet, P., Vogel, T. M. \& Normand, P. (1999). Rhodanobacter lindaniclasticus gen. nov., sp. nov., a lindane-degrading bacterium. Int J Syst Bacteriol 49, 19-23.

Niehaus, F., Bertoldo, C., Kahler, M. \& Antranikian, G. (1999). Extremophiles as a source of novel enzymes for industrial application. Appl Microbiol Biotechnol 51, 711-729.
Palleroni, N. J. (1984). Genus I. Pseudomonas Migula 1894, $237^{A L}$. In Bergey's Manual of Systematic Bacteriology, vol. 1, pp. 141-199. Edited by N. R. Krieg \& J. G. Holt. Baltimore: Williams \& Wilkins.

Palleroni, N. J. \& Bradbury, J. F. (1993). Stenotrophomonas, a new bacterial genus for Xanthomonas maltophilia (Hugh 1980) Swings et al. 1983. Int J Syst Bacteriol 43, 606-609.

Sullivan, R. F., Holtman, M. A., Zylstra, G. J., White, J. F., Jr \& Kobayashi, D. Y. (2003). Taxonomic positioning of two biological control agents for plant diseases as Lysobacter enzymogenes based on phylogenetic analysis of $16 \mathrm{~S}$ rDNA, fatty acid composition and phenotypic characteristics. J Appl Microbiol 94, 1079-1086.

Thompson, J. D., Higgins, D. G. \& Gibson, T. J. (1994). CLUSTAL W: improving the sensitivity of progressive multiple sequence alignment through sequence weighting, position-specific gap penalties and weight matrix choice. Nucleic Acids Res 22, 4673-4680.

Tóth, E., Kovács, G., Schumann, P., Kovács, A. L., Steiner, U., Halbritterá, A. \& Márialigeti, K. (2001). Schineria larvae gen. nov., sp. nov., isolated from the 1st and 2nd larval stages of Wohlfahrtia magnifica (Diptera: Sarcophagidae). Int J Syst Evol Microbiol 51, 401-407.

Vauterin, L., Hoste, B., Kersters, K. \& Swings, J. (1995). Reclassification of Xanthomonas. Int J Syst Bacteriol 45, 472-489.

Vauterin, L., Yang, P. \& Swings, J. (1996). Utilization of fatty acid methyl esters for the differentiation of new Xanthomonas species. Int J Syst Bacteriol 46, 298-304.

Wells, J. M., Raju, B. C., Hung, H.-Y., Weisburg, W. G., MandelcoPaul, L. \& Brenner, J. (1987). Xylella fastidiosa gen. nov., sp. nov.: gram-negative, xylem-limited, fastidious plant bacteria related to Xanthomonas spp. Int J Syst Bacteriol 37, 136-143. 